\title{
Gamblers' Love for Variety and Substitution among Lotto Games
}

\author{
By \\ Victor A. Matheson \\ and \\ Kent Grote
}

September 2006

\section{COLLEGE OF THE HOLY CROSS, DEPARTMENT OF ECONOMICS FACULTY RESEARCH SERIES, PAPER NO. 06-09*}

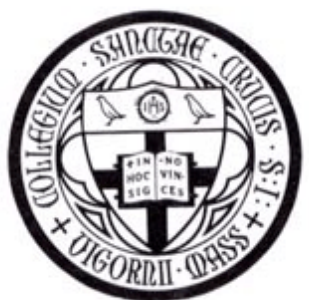

Department of Economics

College of the Holy Cross

Box 45A

Worcester, Massachusetts 01610

(508) 793-3362 (phone)

(508) 793-3710 (fax)

http://www.holycross.edu/departments/economics/website

*All papers in the Holy Cross Working Paper Series should be considered draft versions subject to future revision. Comments and suggestions are welcome. 


\title{
Gamblers' Love for Variety and Substitution among Lotto Games
}

\author{
By
}

\author{
Victor A. Matheson ${ }^{\dagger}$ \\ College of the Holy Cross \\ and \\ Kent Grote $^{\dagger \dagger}$ \\ Lake Forest College
}

September 2006

\begin{abstract}
This paper considers the whether offering multiple lotto games within a state by joining a multi-state lottery increases total ticket sales compared to offering a single state game. The question is considered from two different perspectives, which both lead to the conclusion that states do tend to benefit from increased ticket sales overall by joining a multi-state lottery association. There is, however, a noted difference in the magnitude of that effect depending on the size of the average jackpots of the previously existing state games.
\end{abstract}

JEL Classification Codes: D81, H71, L83

Keywords: lotto, lottery, public finance, gambling

${ }^{\dagger}$ Victor A. Matheson, Department of Economics, Box 157A, College of the Holy Cross, Worcester, MA 01610-2395, 508-793-2649 (phone), 508-793-3710 (fax), vmatheso@holycross.edu

${ }^{\dagger \dagger}$ Kent Grote, Department of Economics and Business, Lake Forest College, Lake Forest, IL 60045, 847-735-5196 (phone), 847-735-6193 (fax), grote@lfc.edu 


\section{Introduction}

While national, state, and local governments offer a variety of legalized gambling products through lottery associations, among the most popular, and the focus of this study, is the set of games known as "lotto," where players select five or six numbers from among 35 to 55 choices (depending on the structure of the game) and win prizes based on the numbers that are correctly matched in a weekly or bi-weekly drawing. A ticket buyer(s) who matches all of the numbers wins the jackpot prize pool while players matching some but not all of the winning numbers win smaller consolation prizes. A unique feature of lotto is that in most games if the jackpot prize is not won in a particular drawing, the money allocated to the jackpot is carried over into the next drawing and is added to funds from ticket sales in the next period. Because the jackpot prize fund is allowed to roll-over in this manner, the jackpot prize can become quite large if no one hits the jackpot in a number of successive periods. Indeed, advertised jackpots exceeding $\$ 50$ million are quite common, and occasionally lotto jackpots have been known to exceed \$300 million.

As of September 2006, 42 states and the District of Columbia had government run lotteries all of which offered at least one lotto game with a roll-over jackpot. Every state except Florida belonged to one of the two major multi-state associations, the twenty-seven state MultiState Lottery Association (Powerball) or the twelve state Big Game/Mega-Millions association. In addition, many states also sell tickets to either another multi-state game or a state lotto that typically offers lower jackpot prizes but better odds. See Table 1 for a list of state lotteries and the lotto games they offer. Note that Table 1 includes only lotto games with a roll-over jackpot. Many states offer lotto-type games that again have players select five or six numbers from among 35 to 55 choices (depending on the structure of the game) and win prizes based on the 
numbers that are correctly matched in a weekly or bi-weekly drawing, but if the jackpot prize is not won in a particular drawing, the money is not carried over into the next drawing. In these games, if the jackpot prize is not won, either the funds allocated to the jackpot prize pool accrue to the lottery authority or the funds "roll-down" to the lower prize tiers and increase the prize amounts received by winners in the other prize categories.

In the 1970 s and 1980s, lottery associations began to experiment with the idea that by offering games with longer odds but bigger grand-prizes, they could attract more buyers. Forrest et al., (2002) have suggested that lotto players are attracted by the high jackpots and not the expected return, and lotto is popular due to the "skewness" of the bet rather than its expected return. Lottery associations realized, however, that if the odds were too high, jackpots would be won very infrequently, and, therefore, the games would not benefit from frequent media exposure surrounding jackpot winners. Lottery officials were forced to choose between offering games with high jackpots and ones with frequent winners.

To this end, in the mid 1970s, state and provincial lottery associations began to join together to offer lotto games beginning with the formation of the Western Canada Lottery Corporation in 1974, the Tri-State Lotto, joining Maine, New Hampshire, and Vermont, in 1985, the Multi-State Lottery Corporation (now more commonly known as Powerball) in 1988, and the Big Game/Mega-Millions Association in 1996. By merging games, states could offer larger jackpots, but the increased number of players would assure that the grand prize was won on a regular basis.

Clotfelter and Cook (1993) suggest that the optimal (or at least most frequent) odds to population ratio for lotto games in the early 1990s was roughly 1 . That is, a lottery association serving a population base of 13 million could offer a game with odds of roughly 1 in 13 million 
and maintain a reasonable frequency of jackpot winners. Until the early 2000s, this meant that states with smaller populations generally offered lotto by being a member of one of the two major multi-state games (Powerball and Big Game/Mega-Millions) while more populous states could offer high prizes through independent lotto games. For example, as of January 2000, eight states (CA, TX, NY, FL, PA, OH, WA, and CO) operated lotto games but not did belong to a multi-state game. Of these eight states, six ranked among the seven largest states by population.

By the early 2000s, however, perhaps due to the record $\$ 300$ million plus jackpots offered during several Powerball and Mega-Millions drawings, even these hold-out states began to join in the multi-state associations so that by July 2005, only Florida remained independent from any multi-state lotto game. Similarly, the national lottery associations of the UK, France and Spain have joined together in February 2004 to offer EuroMillions, which offers among the highest jackpots in Europe.

Lottery associations ultimately must make a choice when faced with the option to join a multi-state (or multi-country) lottery between joining the multi-state game, offering an independent game, or selling tickets to both an independent game and the multi-state lotto game. As shown in Table 1, different lottery associations have made different choices in this regard. Four lottery associations offer only one roll-over lotto game, twenty offer two games, fifteen offer three games, and four state lotteries offer four different games.

The particular focus of this paper is whether offering multiple lotto games increases total ticket sales for the lottery association and under what conditions does joining a large multi-state lottery increase total ticket sales. On the one hand, offering multiple games offers players a variety of games that may appeal to different players depending on the current jackpots, odds of winning, and the players' individual preferences. On the other hand, if the pool of money that 
players make available for gambling is fixed, the introduction of a new game will simply result in substitution from one game to another, cannibalize the existing game, and lead to no net increase in lottery revenues. Lottery revenues may even fall if players have difficulty easily identifying when games achieve particularly high jackpot levels. For example, a 49-choose-6 state lotto game with a 1 in 13 million chance of winning the grand prize might be a particularly attractive bet if the jackpot reaches $\$ 50$ million and would normally have attracted a large number of bettors prior to the introduction of one of the "mega games." However, in the presence of the Powerball or MegaMillions games, which routinely advertise jackpots well in excess of $\$ 100$ million, "jackpot fatigue" can easily set in for the state game.

The issue of substitution among lottery games is not new to the literature. Clotfelter and Cook (1989) test the effects of introducing lotto games on the sales of scratch-card tickets. Stover (1990) finds significant substitution effects between lotteries run by contiguous states. Gulley and Scott (1993), in part of a larger paper, consider the question of whether the two state lotto games in Massachuesetts, the Mass Millions and Mass Megabucks games, serve as substitutes for one another, finding no significant relationship between the two. Forrest, Gully and Simmons (2004) find evidence of some substitution among the variety of games offered by the United Kingdom National Lottery. Finally, Grote and Matheson (2006) find that the introduction of a multi-state game does serve to reduce sales in an existing state lotto games but that the newly generated sales of the multi-state game exceeded the loss of sales in the state game in all three of the cases examined. This paper extends the work of Grote and Matheson (2006) by examining the introduction of the MegaMillions multi-state game to California and Texas. These two states are unique in that even before the introduction of MegaMillions, both states offered games with extremely long odds and large jackpots. It is of particular interest in 
this paper whether adding a multi-state game with similar odds and jackpots to the state's lotto product mix significantly affects total lotto sales.

\section{Estimating the Effect of Joining a Multi-state Game - Model 1}

The most obvious way to examine the gross effects of joining a multi-state lottery would be to compare ticket sales from the state lotto game before the introduction of a new game to the combined ticket sales from both the state and multi-state lotto games after the adoption of a new game. There are two limits to this approach, however. First, state-by-state sales information for the larger multi-state games is not readily available for all states, precluding this as a general methodology. Second, and more importantly, there are likely other variables affecting the sales

of a state's lotto tickets besides the presence of another lottery. To isolate the marginal effect of the presence of a multi-state lottery on the sales of a state lotto game, regression analysis can be used. In particular, one can determine the effect on the smaller game of the member lottery by regressing the sales for the game on a number of independent variables that should affect sales and including a dummy variable for the multi-state game once the state becomes a member. Once the marginal effect of the multi-state game on the state game is determined through regression analysis, the coefficient on the dummy variable can then be compared to the in-state sales generated by the multi-state game (where the data is available) to determine the net effect on sales revenues for the state. The equation used to estimate the effect of a multi-state game on state lotto ticket sales is shown in equation (1).

$$
\text { Sales }=\beta_{0}+\beta_{1}(\text { Jackpot })+\beta_{2}(\text { Jackpot })^{2}+\beta_{3}(\text { Trend })+\beta_{4}(\text { Multi-state })+\epsilon
$$

(Note: time subscripts for each variable have been dropped for simplicity.) 
In addition to the Multi-state dummy variable, which takes on a value of 0 for drawings prior to becoming a multi-state game member and 1 thereafter, the advertised jackpot of the state game, advertised jackpot squared of the state game, and a time trend are also included in the first set of regressions. Since the price of a lotto ticket and the odds of winning remain fixed regardless of the size of the jackpot, the expected return from the purchase of a lottery ticket generally rises along with the size of the jackpot. ${ }^{1}$ It is therefore natural to assume that ticket sales will increase along with the advertised jackpot. "Jackpot squared" is also included as an explanatory variable to reflect the non-linear relationship between ticket sales and advertised jackpots. In general, ticket sales are predicted to increase at an increasing rate relative to the advertised jackpot. This reflects the growing excitement about large jackpots relative to smaller ones. $^{2}$ "Advertised jackpot" and "advertised jackpot squared" have been included in past academic articles such as DeBoer (1990), Shapira and Venezia (1992), Gulley and Scott (1993), Scott and Gulley (1995), Matheson (2001), and Forrest, et al, (2002), as primary explanatory variables for a lottery draw's sales.

A time trend variable is also included to account for the declining popularity in lottery products after they are introduced to the market. This phenomenon has also been examined in the literature by DeBoer (1990). For lotteries that have drawings twice a week (which is all of

\footnotetext{
${ }^{1}$ The exception to this rule comes from fact that if two or more tickets share the winning numbers, the jackpot prize is split among the winners. If the number of ticket buyers rises more rapidly than the jackpot, then the expected return may actually fall despite the larger grand-prize. This type of occurrence, known as "Lotto Fever," has been examined by Matheson and Grote (2004) and has been found to be exceedingly rare. Even on those rare occasions of "Lotto Fever," the excitement of extraordinarily high advertised jackpots entices the additional purchase of lottery tickets despite the lower expected value of the ticket.

${ }^{2}$ Note that the increasing sales relative to jackpots can either be explained by the same number of ticket buyers buying more tickets as jackpots rise or by more ticket buyers purchasing tickets as the higher jackpots increase expected returns enough to attract them to the market.
} 
the lotteries examined in this paper), two separate regressions will be used as there is a distinct difference in the relationship between advertised jackpot levels and sales for drawings that involve sales of tickets over weekends versus those that only involve weekday drawings. This “day" effect for lotteries has been examined more closely in DeBoer (1990), among others.

The data used to estimate equation (1) are drawing by drawing sales for the lotto games of five individual state lottery associations that became members of either the Multi-State Lottery Association (Powerball) or the multi-state Mega Millions game after they had operated as an independent lottery game. The five states and the dates they joined the multi-state games are Colorado (joined Powerball in 2001), New Jersey (joined Big Game/MegaMillions in 1999), Ohio (joined MegaMillions in 2002), Texas (joined MegaMillions in 2003), and California (joined MegaMillions in 2005). These five states were chosen for the availability of data as well as three other factors. First, each state added a multi-state game without making significant changes to their own state game at that time so that sales data for their state game are comparable before and after the addition of the multi-state game. Second, each state provided sufficient lotto sales data both before and after the adoption of the multi-state game to produce credible results. Finally, each state provided both sales data for their own state game as well as the sales within their own state for the multi-state game. Summary statistics for the five selected state lotto games are shown in Table 2.

The results of the regression analyses for equation (1) are provided in Table 3. All of the regressions showed significant evidence of positive first-order serial correlation so the variables used have been adjusted using the Cochrane-Orcutt process to diminish that effect. The DurbinWatson statistics of the original regressions and the rho values used to adjust the variables are included at the bottom of the tables. 
The coefficients on the "Multi-state" dummy variables in Table 3 indicate that for each state lotto game considered, there is a statistically significant decline in sales for the state's own lotto game after it joins the multi-state game ranging from a loss of 437,507 tickets for Saturday drawings in Colorado to a decrease of over 4.3 million in ticket sales in Wednesday draws in California.

While state lotto sales fell, in each case the magnitude of the multi-state dummy variable is smaller than the average per drawing multi-state ticket revenues for each state. Table 5 shows the average sales for the multi-state game after the game's adoption in each state and compares these numbers to the coefficient on the multi-state dummy variable averaged over the two days for each state. As shown in Table 5, even though the states lost revenue on their own game due to the presence of the multi-state game, the increases in overall lotto revenues due to sales of multi-state tickets were greater than those losses, with Texas and New Jersey experiencing an increase of over one million in ticket sales per drawing. Thus, these five states seem to have increased overall state revenues by becoming members of the multi-state lottery. It is interesting to note that California, the state with an existing lotto game with prizes and odds most similar to the multi-state game that was added, experienced the lowest increase in ticket sales among the five states examined. This result becomes even more pronounced when ticket sales are analyzed in a more rigorous fashion in the next section.

\section{Estimating the Effect of Joining a Multi-state Game - Model 2}

Although adding a simple dummy variable for the time period during which a state also belongs to a multi-state game is a very straightforward approach to determining the effect on the sales of the smaller state lottery game, it may not be the most appropriate model. It is possible 
that with the addition of a new game, current purchasers of tickets for a state's own lotto game will not simply reduce their purchases by a fixed amount in each drawing, but will also alter their response to changing jackpot levels in the state game. For example, as noted previously the excitement over a $\$ 50$ million state-lotto jackpot is likely to be considerably reduced given the availability of a multi-state lottery that routinely hits jackpots many times this size. Thus, while ticket buyers should still respond to rising jackpots for the smaller state-run lotto games, it may be that their responses will be dampened after the addition of a larger and more dynamic multistate game. This "dampening" effect can be measured by interacting the multi-state dummy variable with the Jackpot and Jackpot-Squared variables in the regression analysis. The second equation used to estimate the effect of a multi-state game on state lotto ticket sales is shown in equation (2).

$$
\text { Sales }=\beta_{0}+\beta_{1}(\mathrm{JP})+\beta_{2}(\mathrm{JP})^{2}+\beta_{3}(\text { Trend })+\beta_{4}(\mathrm{MS})+\beta_{4}(\mathrm{MS} \times \mathrm{JP})+\beta_{5}(\mathrm{MS} \times \mathrm{JP})^{2}+\epsilon
$$

The regression results for equation (2) including this interaction effect are shown in Table 4. Once the dampening effect is included, an interesting result is revealed. For each state, the coefficient for the multi-state dummy variable is positive not negative as was observed in Table 3 , although in several cases the coefficient is not significantly different from zero at the $5 \%$ level. However, as the advertised jackpot for the state's lotto game increases, there is a significantly smaller increase in ticket sales (as indicated by the negative signs on one or both of the interaction slope dummies for each day and each state) for every dollar added to the jackpot after the state joins a multi-state game. For example, in Wednesday drawings of the Colorado Lotto, prior to the introduction of Powerball, an increase in the jackpot from $\$ 1$ million to $\$ 2$ million 
increased ticket sales by about $\$ 161$ thousand; however, after the introduction of the multi-state game the same increase in the jackpot would only increase ticket sales by about $\$ 35$ thousand. At higher state jackpots, the resulting reductions in sales are even more pronounced. Similar results occur for each of the state lotteries examined and for each day of drawing under at least one of the two slope-dummy variables (if not both).

Taking all three dummy variables into account, one can ascertain that the lotto jackpot does not need to grow very high in order for the overall effect on state ticket sales to become negative in the post multi-state era. For example, considering the Colorado Wednesday drawing, the state lotto jackpot has to grow to only $\$ 1.3$ million dollars before the presence of the Powerball game begins to have a negative impact on Colorado's Wednesday drawing ticket sales. Since \$1.3 million dollars is just above Colorado’s minimum jackpot prize of $\$ 1$ million, the presence of the Powerball game in Colorado is predicted to have an increasingly negative impact on the Wednesday drawing ticket sales for the Colorado lottery game as the state Lotto's jackpot rises. All of the other states similarly reach a negative net impact on the state game at relatively low jackpots. Even Lotto Texas, the game least affected by introduction of the multistate game has to rollover at most four drawings (and reach a jackpot of just over $\$ 11$ million) before the overall impact becomes negative.

The results presented here present evidence for "jackpot fatigue," the phenomenon experienced by many lotteries that large jackpots spur less and less ticket buying over time. Essentially, ticket buyers appear to be responding less to the relatively smaller advertised jackpots for the state game once the multi-state game is introduced, indicating that the addition of a "large jackpot" multi-state game does indeed attract consumers away from the smaller ones. In effect, the large multi-state games are responsible for jackpot fatigue in smaller state games. 
The results in Table 4, as a whole, also result in significantly higher F-scores and $\mathrm{R}^{2 \text {, }} \mathrm{s}$ than the results in Table 3 , although one must be careful in attributing too much significance to this since the variables have been adjusted for serial correlation.

In addition, if one uses the coefficients in Table 4 along with the observed jackpots in the state games after the introduction of the multi-state game, one can estimate what ticket sales would have been in the state games in the five states had they not joined the multi-state game. Again, Table 5 presents these predictions and compares them to actual ticket sales in the state and multi-state games to estimate a net effect of joining the multi-state lotto. The predicted average per drawing increase in revenues from combined ticket sales for the two games is approximately $\$ 380,000$ for Colorado and $\$ 900,000$ for Ohio, very similar outcomes to what was determined from the estimates in Model 1.

Texas and New Jersey also experienced net increases in combined lotto ticket sales following the introduction of the multi-state game, as shown in Table 5, but the increases are much smaller than those estimated in Model 1. Both of these lotto games experienced unexpectedly high jackpots in the period following the introduction of the multi-state game, but because of the observed dampening effect, the increased ticket sales that the state lotto games experienced as a result of the high jackpots were lower than would have occurred in the absence of the multi-state game. For example, the jackpot for Lotto Texas for the June 19, 2004 drawing (after Texas had joined MegaMillions) reached a record $\$ 145$ million, yet ticket sales for this drawing were lower than the sales for a $\$ 70$ million jackpot just two years earlier (before Texas had joined a multistate game). Under Model 2, California actually experienced lower combined ticket sales after joining MegaMillions than they did when they offered only a single game. 
The final column of Table 5 presents the most interesting results and provides an important lesson for lottery associations. Colorado's combined lotto sales increased by just over $30 \%$, the largest percentage increase of any of the five states examined, following the

introduction of Powerball. Colorado also had the lowest average jackpots of any of the five state lotto games, so that joining MUSL resulted in the addition of a lottery product that was distinctly different than their own existing state lotto game. New Jersey, Ohio, and Texas, with larger average state lotto jackpots prior to joining MegaMillions, experienced smaller percentage gains in total ticket sales. California, with by far the largest average jackpots and prizes rivaling those of the multi-state game it joined, experienced an estimated $4 \%$ decrease in combined ticket sales after the adoption of MegaMillions.

\section{Conclusions}

There is little doubt that smaller state-run games lose ticket buyers when a state joins a multi-state lottery association. Furthermore, following the introduction of a multi-state game, ticket buyers within a state become less responsive to changes in the state lotto game leading to "jackpot fatigue." However, the evidence suggests that the combined ticket sales of the state and multi-state game rise when a multi-state game is introduced. This effect, however, is smaller for states with existing lotto games that offer relatively larger jackpots. In these cases, the addition of a large jackpot multi-state game provides relatively less additional variety to players than the addition of a multi-state game in a state previously offering only a low jackpot game. The conclusion that "variety matters" is supported even further by the result in California, the state that offers the highest advertised jackpots in its state game. In California, the introduction of the multi-state game actually reduced state lotto sales by such a large margin that these losses 
exceeded the ticket sales in the newly introduced multi-state game. Clearly, states should consider the issue of product differentiation when either choosing to join larger multi-state lottery games or when offering the other smaller lottery products to their residents. 


\section{REFERENCES}

Clotfelter, Charles T. and Cook, Philip J. Selling Hope. Cambridge, MA: Harvard University Press, 1989.

Clotfelter Charles T. and Cook, Philip J. "The Peculiar Scale Economies of Lotto," American Economic Review, June 1993, 83:3, 634-643.

DeBoer, Larry. “Lotto Sales Stagnation: Product Maturity or Small Jackpots?” Growth and Change, Winter 1990, 73-7.

Forrest, David, Gulley, O. David and Simmons, Robert. "Elasticity of Demand for UK National Lottery Tickets," National Tax Journal, December 2000, 853 - 63.

Forrest, David, Gulley, O. David and Simmons, Robert. "Substitution between Games in the UK National Lottery," Applied Economics, April 2004, 645-51.

Forrest, David, Simmons, Robert and Chesters, N. " Buying a Dream: Alternative Models of Demand for Lotto,” Economic Inquiry, 40:3, July 2002, 485-96.

Grote, Kent R. and Matheson, Victor A. "Dueling Jackpots: Are Competing Lotto Games Complements or Substitutes?” Atlantic Economic Journal, March 2006, 34:1, 85-100.

Gully, O. David and Scott, Frank A., Jr. "The Demand for Wagering on State-Operated Lotto Games," National Tax Journal. March 1993, 13-22.

Matheson, Victor A. "When are State Lotteries a Good Bet? (Revisited)," Eastern Economic Journal, Winter 2001, 55-70.

Matheson, Victor A. and Grote, Kent R. "Lotto Fever: Do Lottery Players Act Rationally Around Large Jackpots?” Economics Letters, May 2004, 233-7.

Scoggins, John F. “The Lotto and Expected Net Revenue," National Tax Journal, March 1995, 61-70.

Scott, Frank A., Jr. and Gully, O. David. "Testing for Efficiency in Lotto Markets," Economic Inquiry, April 1995, 175-88.

Shapira, Zur and Venezia, Itzhak. "Size and Frequency of Prizes as Determinants of the Demand for Lotteries" Organizational Behavior and Human Decision Processes, July 1992, 307-18.

Stover, M.E. “Contiguous State Lotteries: Substitutes or Complements?” Journal of Policy Analysis and Management, 1990, 565-8. 
Table 1: State and Multi-state Lotto Games Offered in the United States

State

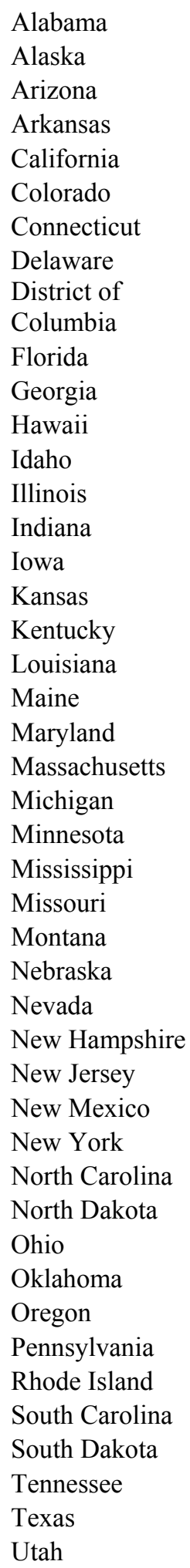

State lotto games offered

None

None

The Pick

None

SuperLotto Plus, Fantasy 5

Lotto

Classic Lotto

Multi-Win Lotto

Rolling Cash

Lotto, Mega Money

Fantasy 5

None

None

Lotto, Little Lotto

Hoosier Lotto

None

Kansas Cash

Cash Ball

Lotto

None

Multi-match

Megabucks, Cash Windfall

Fantasy 5, Classic Lotto 47

Gopher 5, Northstar Cash

None

Lotto

Montana Cash

Pick 5

None

None

Pick Six, Jersey Cash 5

Roadrunner Cash

Lotto

None

None

Rolling Cash 5, Lot 'O Play

None

Megabucks

Match 6, Cash 5

Wild Money

None

Dakota Cash

Lotto 5

Lotto Texas, Texas Two Step

None
Multi-state lotto games offered

None

None

Powerball

None

Mega-Millions

Powerball

Powerball

Powerball

Powerball, Hot Lotto

None

Mega-Millions

None

Powerball, Wild Card Lotto

Mega-Millions

Powerball

Powerball, Hot Lotto

Powerball, Hot Lotto

Powerball

Powerball

Powerball, Tri-state Megabucks, Triple Play

Mega-Millions

Mega-Millions

Mega-Millions

Powerball, Hot Lotto

None

Powerball

Powerball, Hot Lotto, Wild Card Lotto

Powerball

None

Powerball, Tri-state Megabucks, Triple Play, Hot Lotto

Mega-Millions

Powerball

Mega-Millions

Powerball

Powerball, Hot Lotto, Wild Card Lotto

Mega-Millions

Powerball

Powerball

Powerball

Powerball

Powerball

Powerball, Hot Lotto, Wild Card Lotto

Powerball

Mega-Millions

None 


$\begin{array}{lll}\text { Vermont } & \text { None } & \text { Powerball, Tri-state Megabucks, Triple Play } \\ \text { Virginia } & \text { None } & \text { Mega-Millions } \\ \text { Washington } & \text { Lotto, Quinto } & \text { Mega-Millions } \\ \text { West Virginia } & \text { None } & \text { Powerball, Hot Lotto } \\ \text { Wisconsin } & \text { Megabucks, Badger } 5 & \text { Powerball } \\ \text { Wyoming } & \text { None } & \text { None }\end{array}$


Table 2: Summary Statistics for Data used in first two regression models

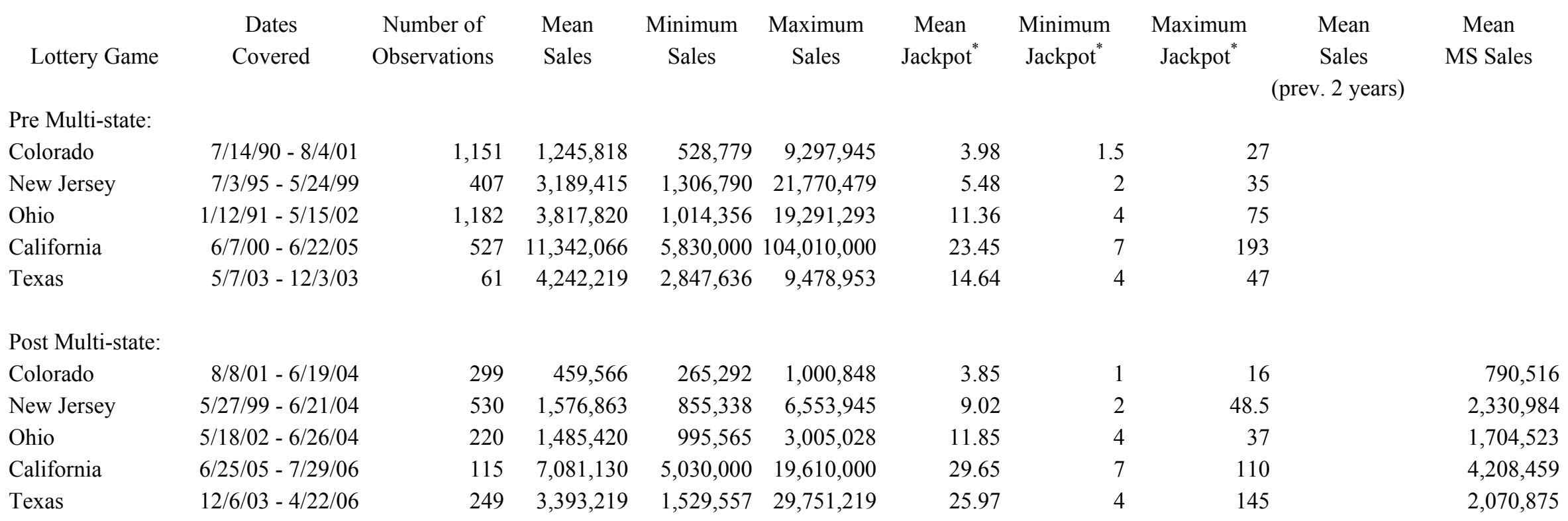

${ }^{*}$ Numbers are in millions of dollars. 
Table 3: Presence of Multi-State Game - Model 1

\begin{tabular}{|c|c|c|c|c|c|c|c|c|c|c|}
\hline Variable & $\begin{array}{c}\text { Colorado } \\
\text { Wed }\end{array}$ & $\begin{array}{c}\text { Colorado } \\
\text { Sat }\end{array}$ & $\begin{array}{c}\text { New Jersey } \\
\text { Mon }\end{array}$ & $\begin{array}{c}\text { New Jersey } \\
\text { Th }\end{array}$ & $\begin{array}{l}\text { Ohio } \\
\text { Wed }\end{array}$ & $\begin{array}{c}\text { Ohio } \\
\text { Sat }\end{array}$ & $\begin{array}{c}\text { California } \\
\text { Wed }\end{array}$ & $\begin{array}{c}\text { California } \\
\text { Sat }\end{array}$ & $\begin{array}{l}\text { Texas } \\
\text { Wed }\end{array}$ & $\begin{array}{c}\text { Texas } \\
\text { Sat }\end{array}$ \\
\hline Constant & $\begin{array}{r}799,240^{* *} \\
(16.04)\end{array}$ & $\begin{array}{r}1,060,735^{* *} \\
(22.59)\end{array}$ & $\begin{array}{r}2,338,138^{* *} \\
(16.52)\end{array}$ & $\begin{array}{r}2,714,621^{* *} \\
(14.15)\end{array}$ & $\begin{array}{r}3,197,167^{* *} \\
(25.48)\end{array}$ & $\begin{array}{r}3,363,972^{* *} \\
(29.11)\end{array}$ & $\begin{array}{r}8,038,269^{* *} \\
(13.16)\end{array}$ & $\begin{array}{r}8,172,267^{* *} \\
(14.67)\end{array}$ & $\begin{array}{r}4,565,592^{* *} \\
(18.91)\end{array}$ & $\begin{array}{r}4,489,259^{*} \\
(20.97)\end{array}$ \\
\hline Jackpot & $\begin{array}{r}109,357^{* *} \\
(14.50)\end{array}$ & $\begin{array}{r}54,633^{* *} \\
(5.93)\end{array}$ & $\begin{array}{r}251,653^{* *} \\
(17.20)\end{array}$ & $\begin{array}{r}211,880^{* *} \\
(10.13)\end{array}$ & $\begin{array}{r}92,826^{* *} \\
(9.10)\end{array}$ & $\begin{array}{r}140,759^{* *} \\
(17.01)\end{array}$ & $\begin{array}{r}58,382^{* *} \\
(3.21)\end{array}$ & $\begin{array}{r}85,531^{* *} \\
(5.92)\end{array}$ & $\begin{array}{r}-67,920^{* *} \\
(-7.56)\end{array}$ & $\begin{array}{r}-20,363^{*} \\
(-2.74\end{array}$ \\
\hline Jackpot $^{2}$ & $\begin{array}{r}7,537.7^{* *} \\
(16.34)\end{array}$ & $\begin{array}{r}11,630^{* *} \\
(18.02)\end{array}$ & $\begin{array}{r}-3,730.9^{* *} \\
(-9.02)\end{array}$ & $\begin{array}{r}-1,729.9^{* *} \\
(-2.94)\end{array}$ & $\begin{array}{r}3,857.0^{* *} \\
(14.20)\end{array}$ & $\begin{array}{r}1,886.9^{* *} \\
(9.45)\end{array}$ & $\begin{array}{r}2,778.1^{* *} \\
(15.16)\end{array}$ & $\begin{array}{r}2,326.9^{* *} \\
(21.40)\end{array}$ & $\begin{array}{r}2,162.8^{* *} \\
(21.72)\end{array}$ & $\begin{array}{r}1,381.1^{*} \\
(20.13)\end{array}$ \\
\hline Time & $\begin{array}{r}-752.9^{* *} \\
(-5.46)\end{array}$ & $\begin{array}{r}-951.0^{* *} \\
(-7.76)\end{array}$ & $\begin{array}{r}-4,053.8^{* *} \\
(-4.71)\end{array}$ & $\begin{array}{r}-4,948.5^{* *} \\
(-4.30)\end{array}$ & $\begin{array}{r}-4,398.6^{* *} \\
(-14.60)\end{array}$ & $\begin{array}{r}-4,666.5^{* *} \\
(-16.44)\end{array}$ & $\begin{array}{r}-8,064.8^{*} \\
(-2.22)\end{array}$ & $\begin{array}{r}-8,483.3^{*} \\
(-2.54)\end{array}$ & $\begin{array}{r}-12,489^{* *} \\
(-4.40)\end{array}$ & $\begin{array}{r}-14,594^{*} \\
(-5.87)\end{array}$ \\
\hline Multi-state & $\begin{array}{r}-440,850^{* *} \\
(-6.29)\end{array}$ & $\begin{array}{r}-437,507^{* *} \\
(-6.98)\end{array}$ & $\begin{array}{r}-1,060,661^{* *} \\
(-4.53)\end{array}$ & $\begin{array}{r}-1,073,350^{* *} \\
(-3.42)\end{array}$ & $\begin{array}{r}-804,628^{* *} \\
(-4.84)\end{array}$ & $\begin{array}{r}-796,516^{* *} \\
(-5.10)\end{array}$ & $\begin{array}{r}-4,325,794^{* *} \\
(-5.07)\end{array}$ & $\begin{array}{r}-3,998,640^{* *} \\
(-5.06)\end{array}$ & $\begin{array}{r}-823,120^{* *} \\
(-2.60)\end{array}$ & $\begin{array}{r}-576,129 \\
(-2.02)\end{array}$ \\
\hline $\mathrm{N}$ & 723 & 725 & 467 & 467 & 699 & 701 & 320 & 320 & 154 & 154 \\
\hline $\mathrm{R}$-square & 0.871 & 0.855 & 0.631 & 0.527 & 0.850 & 0.839 & 0.892 & 0.918 & 0.905 & 0.921 \\
\hline dj. R-square & 0.871 & 0.854 & 0.623 & 0.533 & 0.849 & 0.838 & 0.891 & 0.917 & 0.902 & 0.919 \\
\hline $\mathrm{F}$ & $1,215.24^{* *}$ & $1,063.43^{* *}$ & $197.58^{* *}$ & $128.66^{* *}$ & $982.53^{* *}$ & $904.11^{* *}$ & $650.43^{* *}$ & $883.26^{* *}$ & $352.78^{* *}$ & $436.44^{*}$ \\
\hline DW & 0.977 & 1.109 & 1.368 & 1.42 & 1.317 & 1.348 & 1.023 & 1.240 & 1.170 & 1.607 \\
\hline Rho & 0.545 & 0.484 & 0.432 & 0.389 & 0.361 & 0.343 & 0.488 & .380 & 0.415 & 0.288 \\
\hline
\end{tabular}

The number in parentheses below each coefficient is the respective t-score for that coefficient.

${ }^{* *}$ Significant at $1 \%$ level

${ }^{*}$ Significant at $5 \%$ level 
Table 4: Presence of Multi-State Game - Model 2

\begin{tabular}{|c|c|c|c|c|c|c|c|c|c|c|}
\hline Variable & $\begin{array}{c}\text { Colorado } \\
\text { Wed }\end{array}$ & $\begin{array}{c}\text { Colorado } \\
\text { Sat }\end{array}$ & $\begin{array}{c}\text { New Jersey } \\
\text { Mon }\end{array}$ & $\begin{array}{c}\text { New Jersey } \\
\text { Th }\end{array}$ & $\begin{array}{l}\text { Ohio } \\
\text { Wed }\end{array}$ & $\begin{array}{l}\text { Ohio } \\
\text { Sat }\end{array}$ & $\begin{array}{l}\text { California } \\
\text { Wed }\end{array}$ & $\begin{array}{c}\text { California } \\
\text { Sat }\end{array}$ & $\begin{array}{l}\text { Texas } \\
\text { Wed }\end{array}$ & $\begin{array}{c}\text { Texas } \\
\text { Sat }\end{array}$ \\
\hline Constant & $\begin{array}{r}714,757^{* *} \\
(23.27)\end{array}$ & $\begin{array}{r}982,614^{* *} \\
(32.73)\end{array}$ & $\begin{array}{r}2,021,527^{* *} \\
(26.89)\end{array}$ & $\begin{array}{r}2,360,948^{* *} \\
(32.21)\end{array}$ & $\begin{array}{r}2,956,327^{* *} \\
(31.02)\end{array}$ & $\begin{array}{r}3,116,957^{* *} \\
(36.35)\end{array}$ & $\begin{array}{r}7,273,100^{* *} \\
(26.36)\end{array}$ & $\begin{array}{r}7,059,022^{*} \\
(21.84)\end{array}$ & $\begin{array}{r}2,724,364^{* *} \\
(6.07)\end{array}$ & $\begin{array}{r}3,364,054^{* *} \\
(8.77)\end{array}$ \\
\hline Jackpot & $\begin{array}{r}140,503^{* *} \\
(23.50)\end{array}$ & $\begin{array}{r}80,506^{* *} \\
(11.37)\end{array}$ & $\begin{array}{r}244,419^{* *} \\
(18.23)\end{array}$ & $\begin{array}{r}154,086^{* *} \\
(15.47)\end{array}$ & $\begin{array}{r}118,833^{* *} \\
(13.46)\end{array}$ & $\begin{array}{r}166,863^{* *} \\
(23.19)\end{array}$ & $\begin{array}{r}72,779^{* *} \\
(6.14)\end{array}$ & $\begin{array}{r}137,396^{* *} \\
(12.23)\end{array}$ & $\begin{array}{r}38,519 \\
(1.63)\end{array}$ & $\begin{array}{r}55,304.4 \\
(1.16)\end{array}$ \\
\hline Jackpotsq & $\begin{array}{r}6,929.8^{* *} \\
(19.37)\end{array}$ & $\begin{array}{r}11,489^{* *} \\
(23.57)\end{array}$ & $\begin{array}{r}3,370.0^{* *} \\
(6.03)\end{array}$ & $\begin{array}{r}9,477.0^{* *} \\
(26.88)\end{array}$ & $\begin{array}{r}3,634.7^{* *} \\
(15.73)\end{array}$ & $\begin{array}{r}1,696.8^{* *} \\
(10.01)\end{array}$ & $\begin{array}{r}3,042.1^{* *} \\
(25.07)\end{array}$ & $\begin{array}{r}2,157.0^{* *} \\
(25.76)\end{array}$ & $\begin{array}{r}2,143.8^{* *} \\
(4.11)\end{array}$ & $\begin{array}{r}1,348.8 \\
(1.16)\end{array}$ \\
\hline Time & $\begin{array}{l}-838.2^{* *} \\
(-10.33)\end{array}$ & $\begin{array}{r}-1,020.8^{* *} \\
(-13.89)\end{array}$ & $\begin{array}{r}-4,397.4^{* *} \\
(-11.16)\end{array}$ & $\begin{array}{r}-4,623.7^{* *} \\
(-11.17)\end{array}$ & $\begin{array}{r}-4,428.3^{* *} \\
(-21.04)\end{array}$ & $\begin{array}{r}-4,715.3^{* *} \\
(-24.52)\end{array}$ & $\begin{array}{r}-6,541.5^{* *} \\
(-4.41)\end{array}$ & $\begin{array}{r}-7,848.6^{* *} \\
(-4.37)\end{array}$ & $\begin{array}{r}-12,161^{* *} \\
(-2.72)\end{array}$ & $\begin{array}{r}-13,916^{* *} \\
(-7.47)\end{array}$ \\
\hline Multi-state & $\begin{array}{r}142,339^{*} \\
(2.18)\end{array}$ & $\begin{array}{r}22,692 \\
(0.35)\end{array}$ & $\begin{array}{r}481,867^{* *} \\
(3.78)\end{array}$ & $\begin{array}{r}240,033 \\
(1.89)\end{array}$ & $\begin{array}{r}945,492^{* *} \\
(3.43)\end{array}$ & $\begin{array}{r}1,184,073^{* *} \\
(4.70)\end{array}$ & $\begin{array}{r}304,588 \\
(.49)\end{array}$ & $\begin{array}{r}1,107,051 \\
(1.38)\end{array}$ & $\begin{array}{r}1,872,930^{* *} \\
(4.17)\end{array}$ & $\begin{array}{r}816,988 \\
(1.92)\end{array}$ \\
\hline MS x Jackpot & $\begin{array}{r}-105,143^{* *} \\
(-4.98)\end{array}$ & $\begin{array}{r}-41,011 \\
(-1.84)\end{array}$ & $\begin{array}{r}-178,639^{* *} \\
(-10.95)\end{array}$ & $\begin{array}{r}-90,141^{* *} \\
(-6.79)\end{array}$ & $\begin{array}{r}-97,271^{* *} \\
(-2.49)\end{array}$ & $\begin{array}{r}-145,301^{* *} \\
(-4.27)\end{array}$ & $\begin{array}{r}-92,306^{* *} \\
(-3.01)\end{array}$ & $\begin{array}{r}-128,530^{* *} \\
(-2.96)\end{array}$ & $\begin{array}{r}-161,176^{* *} \\
(-6.57)\end{array}$ & $\begin{array}{r}-96,249^{*} \\
(-1.99)\end{array}$ \\
\hline $\begin{array}{r}\text { MS x } \\
\text { Jackpotsq }\end{array}$ & $\begin{array}{r}-7,144.9^{* *} \\
(-4.42)\end{array}$ & $\begin{array}{r}-12,039^{* *} \\
(-6.94)\end{array}$ & $\begin{array}{r}-3,558.3^{* *} \\
(-5.84)\end{array}$ & $\begin{array}{r}-9,627.9^{* *} \\
(-22.91)\end{array}$ & $\begin{array}{r}-3,233.0^{* *} \\
(-2.74)\end{array}$ & $\begin{array}{r}-1,253.1 \\
(-1.30)\end{array}$ & $\begin{array}{r}-1,775.5^{* *} \\
(-5.61)\end{array}$ & $\begin{array}{r}-1,301.7^{* *} \\
(-2.71)\end{array}$ & $\begin{array}{l}565.6 \\
(.284)\end{array}$ & $\begin{array}{r}210.0 \\
(.18)\end{array}$ \\
\hline $\mathrm{N}$ & 723 & 725 & 467 & 467 & 699 & 701 & 321 & 320 & 154 & 154 \\
\hline R-square & 0.932 & 0.927 & 0.917 & 0.956 & 0.902 & 0.896 & 0.961 & 0.958 & .970 & 0.943 \\
\hline Adj. R-square & 0.931 & 0.927 & 0.916 & 0.955 & 0.901 & 0.895 & 0.96 & 0.957 & 0.968 & 0.94 \\
\hline $\mathrm{F}$ & $1,629.78^{* *}$ & $1,529.40^{* *}$ & $842.27^{* *}$ & $1,665.85^{* *}$ & $1,061.25^{* *}$ & $996.23^{* *}$ & $1,290.83^{* *}$ & $1,181.69^{* *}$ & $781.55^{* *}$ & $402.51^{* *}$ \\
\hline DW & 1.173 & 1.236 & 1.216 & 1.07 & 1.505 & 1.595 & 1.481 & 1.677 & 0.939 & 1.813 \\
\hline Rho & 0.435 & 0.389 & 0.405 & 0.486 & 0.254 & 0.206 & 0.258 & 0.161 & 0.807 & 0.152 \\
\hline
\end{tabular}

The number in parentheses below each coefficient is the respective t-score for that coefficient.

${ }^{* *}$ Significant at $1 \%$ level

${ }^{*}$ Significant at $5 \%$ level 
Table 5: Net Effect of Multi-state Lotto on Total Lotto Sales

\begin{tabular}{|c|c|c|c|c|c|c|c|c|}
\hline State & $\begin{array}{c}\text { Average state game } \\
\text { sales } \\
\text { (Pre multi-state game) }\end{array}$ & $\begin{array}{l}\text { Average multi-state game } \\
\text { sales } \\
\text { (Post multi-state game) }\end{array}$ & $\begin{array}{l}\text { Average loss in } \\
\text { state game sales } \\
\text { (Post MS) }\end{array}$ & $\begin{array}{l}\text { Net gain } \\
\text { State + MS } \\
\text { (Post MS) }\end{array}$ & $\begin{array}{l}\text { Percentage } \\
\text { gain } \\
\text { (Post MS) }\end{array}$ & $\begin{array}{l}\text { Average loss in } \\
\text { state game sales } \\
\text { (Post MS) }\end{array}$ & $\begin{array}{c}\text { Net gain } \\
\text { State + MS } \\
\text { (Post MS) }\end{array}$ & $\begin{array}{l}\text { Percentage } \\
\text { gain } \\
\text { (Post MS) }\end{array}$ \\
\hline & & & Model 1 & Model 1 & Model 1 & Model 2 & Model 2 & Model 2 \\
\hline Colorado & $1,245,818$ & 790,516 & $-439,178$ & 351,338 & $28.20 \%$ & $-413,149$ & 377,367 & $30.29 \%$ \\
\hline New Jersey & $3,189,415$ & $2,330,984$ & $-1,067,006$ & $1,263,979$ & $39.63 \%$ & $-1,933,222$ & 397,762 & $12.47 \%$ \\
\hline Ohio & $3,817,820$ & $1,704,523$ & $-800,572$ & 903,951 & $23.68 \%$ & $-803,788$ & 900,735 & $23.59 \%$ \\
\hline California & $11,342,066$ & $4,208,459$ & $-4,162,217$ & 46,242 & $0.41 \%$ & $-4,697,432$ & $-488,973$ & $-4.31 \%$ \\
\hline Texas & $4,242,219$ & $2,070,875$ & $-699,624$ & $1,371,251$ & $32.32 \%$ & $-1,558,745$ & 512,130 & $12.07 \%$ \\
\hline
\end{tabular}

